Received 28 July 2021

Accepted 20 September 2021

Published: 28 February 2022

Link to DOI:

$\underline{10.25220 / \mathrm{WNJ} . V 05.12 .0005}$

Citation: Rosa AI, Sunardi D, Hardiany NS. Correlation of zinc intake with hair zinc levels and appetite in children aged 2-3 years in Jakarta. World Nutrition Journal.2022 Feb 28, 5(2):23-31.

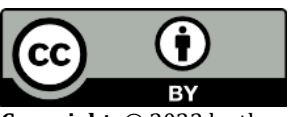

Copyright: (C) 2022 by the authors. This article is an open access article distributed under the terms and conditions of the Creative Commons Attribution (CC BY) license (https:// creativecommons.org/licenses/b y/ 4.0/).

Website http://www.worldnutrijourna lorg

\title{
Correlation of zinc intake with hair zinc levels and appetite in children aged 2-3 years in Jakarta
}

\author{
Anin Ika Rosa ${ }^{1}$,Diana Sunardi ${ }^{2}$,Novi Silvia Hardiany ${ }^{3}$ \\ 1. Faculty of Medicine, Universitas Indonesia \\ 2. Department of Nutrition, Faculty of Medicine, Universitas Indonesia, Cipto Mangunkusumo \\ Hospital \\ 3. Department of Biochemistry, Faculty of Medicine, Universitas Indonesia, Cipto Mangunkusumo \\ Hospital
}

\begin{abstract}
Background: Children under five years experience rapid growth and development, so that adequate nutritional intake is very important. Zinc is essential for child development and growth. Children's zinc requirements are fulfilled from daily food intake that might be affected by Covid-19 pandemic. The aim of this study is to determine the correlation between zinc intake with hair zinc level and appetite in children aged 2-3 years in Jakarta.

Methods: This cross-sectional study was carried out from September to October 2020 in Kampung Melayu, Jakarta. Seventy children aged 2-3 years were taken using total population sampling method. Interviews were conducted to obtain characteristic data and zinc intake using semi quantitative-food frequency questionnaire (SQ-FFQ). Appetite were assessed using VAS appetite questionnaire. Hair samples were collected to check level of hair zinc. Spearman correlation was performed using SPSS.

Results: Median of zinc intake was $6(1,2-22,5) \mathrm{mg} /$ day, with $20 \%$ of the subjects had insufficient zinc intake. The median hair zinc value was $132(30-451) \mu \mathrm{g} / \mathrm{g}$, with $17,1 \%$ subjects zinc insufficient. The median of VAS appetite score was $54,5 \mathrm{~mm}$. There were no significant correlation between zinc intake and hair zinc level $(r=-0.077, p=0.528)$. A weak positive correlation was found between appetite and hair zinc levels $(r=0,247, p=0,039)$.

Conclusion: Zinc intake in children aged 2-3 years had no significant correlation with hair zinc level, and appetite had a weak positive correlation with hair zinc level.

Keywords: children aged 2-3 years, hair zinc, zinc intake, VAS appetite
\end{abstract}

\section{Introduction}

Children under five years experience rapid growth and development, so that adequate nutritional intake is very important. In a study of preschool-aged children in Jakarta, the prevalence of eating difficulties was $33.6 \% .^{1}$ This problem makes nutritional needs unfulfilled, which can lead to malnutrition and growth disorders. ${ }^{2}$ Feeding

\section{Corresponding author:}

DR. dr. Diana Sunardi, MGizi, SpGK

Department of Nutrition, Faculty of Medicine, Universitas

Indonesia

Email : diana_sunardi@yahoo.com problems are more important among preschoolers who have high energy needs especially in children under five years of age. ${ }^{2}$ Two years of age is a period of weaning from breast milk and complementary feeding, since then children are expected to have eaten similar food as their family, both in type and composition, age 2 to 3 years old is a very important transition period to pursue growth after the golden period. Therefore, it is important to pay attention to zinc intake at this age bracket to support optimal child growth.

Micronutrients that are important during growth are vitamins $\mathrm{A}, \mathrm{C}, \mathrm{D}, \mathrm{E}, \mathrm{B}$, selenium and zinc. Unlike other minerals, zinc does not have large 
storage that can keep or release zinc according to variations in food intake, therefore adequacy of zinc is important. Research by Chao et al. ${ }^{3}$ showed that zinc supplementation in malnourished children could increase appetite and growth.

The global prevalence of zinc deficiency is $31 \%$ with a range of $4 \%$ to $73 \%$. The highest prevalence is found in Southeast and South Asia (34\%-73\%). ${ }^{4}$ Zinc deficiency is more likely to occur during childhood, when daily zinc requirements are higher. Zinc deficiency can cause loss of appetite, which can have an impact on nutritional status and growth. Hair zinc levels can describe chronic zinc status, is more stable and is not affected by rapid fluctuations from diurnal and dietary variations, and is also more suitable for use in children because it is less invasive than plasma or serum zinc.

Hair zinc examination is a marker that can show a person's zinc status. The concentration of zinc in hair is the second largest concentration after zinc in teeth, which is $200 \mathrm{mg} / \mathrm{kg}$ by weight. The zinc concentration in hair is more stable and is not affected by rapid fluctuations associated with diurnal variations, diet, etc. Another advantage is that there is no trauma due to the sampling, it does not require preservatives or a certain temperature. ${ }^{5}$

The body needs more zinc during periods of rapid growth such as pregnancy, infancy, childhood and adolescence. The need for zinc for Indonesian children varies according to their age. At the age of 1-3 years, the need is $3 \mathrm{mg} / \mathrm{day} .{ }^{6}$ Foods rich in zinc are seafood, meat, whole grains, nuts, and dairy products. The difference between zinc intake and absorption must be considered, because even if zinc intake is adequate, levels of inhibitors (fiber and phytate) in the diet can prevent zinc from being absorbed adequately. ${ }^{7}$

Visual analog scale (VAS) questionnaire is widely used in nutrition research to assess appetite and food intake. VAS is correlated with energy intake, and can predict eating motivation in subjects who eat a normal diet in a normal environment. ${ }^{8}$ Several studies have used the VAS in children and adolescents to assess hunger and satiety. ${ }^{9}$ Subjects were asked to answer questions by marking on a 100 mm line with the left end meaning "not at all" and the right end meaning "extremely". Variations of
VAS are in the form of 10-point Likert scale, bipolar and unipolar scale, $150 \mathrm{~mm}$ horizontal line, and 7point scale with qualitative labels at the same distance. However, a $100 \mathrm{~mm}$ horizontal line without markings except for labels at both ends is the most widely used form of VAS. ${ }^{9}$ Several studies of appetite in children had used VAS with assessment by parents. Research conducted in the Philippines and Taiwan used VAS questionnaire for parents to assess their child's appetite. ${ }^{10,11}$ The VAS is filled at set times, usually just before and after one feeding episode and periodically at intervals between meals (usually 1 hour). In this study, VAS is filled one time by subject's parent/caregiver expressing current time child's appetite.

Covid-19 pandemics has altered many aspect of the society including the eating habits that has impacts on children' nutritional status. In long term, this will lead to altered zinc status and it's function. The aim of this study is to determine the correlation between zinc intake with hair zinc level and appetite in children aged 2-3 years in Jakarta.

\section{Methods}

This cross-sectional study design was carried out during the Covid-19 pandemic, from September to October 2020 in Kampung Melayu Sub-district, East Jakarta. Location of the study was chosen because it was the only limited resources that provided permission to do data collection due to Covid-19 pandemic.

\section{Subjects}

The subjects of this study were apparently healthy children aged 2-3 years old, with permission to participate in the study from their parents. Subject selection was carried out by total population sampling. The subject's parents or guardians were explained about the purpose, benefits and examinations that would be taken. Parents who agreed to take part in this study signed the consent form. Children with acute and chronic infection, severe malnutrition, liver disorders, malabsorption syndrome, congenital diseases, and hair length didn't sufficient for sampling were excluded from 
the study. Total 70 samples were met the criteria for this study and furthered analyzed.

\section{Characteristic Data}

Data on subjects' characteristics include: age, gender, maternal education, family income, income during pandemic, and the impact of the pandemic on children's food were collected from interviews. Maternal education was categorized into high (high school education and above) and low (below high school education). Family income was categorized based on minimum wage (UMP) DKI Jakarta 2020 (Rp. 4.276.350) to be more or equal to the UMP and less than the UMP.

Zinc intake, anthropometric measurement, and appetite assessment

Assessment of food intake was taken using a semi quantitative questionnaire (SQ-FFQ) to determine the subjects' zinc intake. Interviews were conducted using a food photo book. Anthropometric measurement taken were body weight and height. Subjects' body weight was measured using SECA digital scale, with accuracy $0,1 \mathrm{~kg}$. Subject's height was measured using a SECA stadiometer with accuracy $0,1 \mathrm{~cm}$. Each measurement was taken twice and the average value was calculated. Nutritional status was determined based on the WHO growth chart Z-score weight/height. Appetite was assessed by using Visual Analog Scale (VAS) which have 3 questions with extreme value in each side of the $100 \mathrm{~mm}$ line. The questions were asked to the parents or guardian of the subjects.

\section{Laboratory examination}

Hair samples were collected to check the level of hair zinc. The hair zinc test was conducted in collaboration with Prodia Laboratory. Hair sample was taken in the Kampung Melayu Sub-district office by laboratory staff. The number of hair 10-15 strands and taken at 5 different places, was cut as close as possible to the hair roots, taken $2.5 \mathrm{~cm}$ from the closest to the base of the hair and the rest discarded. Then the hair samples were taken to Prodia laboratory for analysis. Examination of hair zinc levels using the Atomic Absorption Spectrophotometry (AAS) method using Agilent Inductively Coupled Plasma-Mass Spectrometry (ICP-MS) 7700 series.

\section{Data analysis}

Data were analyzed using SPSS version 20.0. Normality of the data distribution was determined by Kolmogorov Smirnof test. Data distribution was considered normal when $p$ value $\geq 0,05$. Data are presented in the form of mean \pm standard deviation (SD) if normally distributed ( $\mathrm{p} \geq 0.05)$, and in the form of median (minimum-maximum) if not normally distributed $(\mathrm{p}<0.05)$. Categorical data were presented in the form of frequency distribution $(\mathrm{n}, \%)$. Continuous data were presented in the form of median (minimum-maximum). The correlation between two variables was analyzed using the Pearson correlation test if the data distribution was normal, or the Spearman Rank correlation test if the data distribution was not normal. The possible range of values for the correlation coefficient (r) is -1 to 1 . A correlation of -1 indicates a perfect negative correlation, and a correlation of 1 indicates a perfect positive correlation. Value 0,8 to 1 indicate very strong correlation, 0,6 to 0,8 indicate strong correlation, 0,4 to 0,6 indicate moderate correlation, 0,2 to 0,4 indicate weak correlation, and $<0,2$ indicate very weak correlation. If the correlation coefficient is greater than zero, it is a positive relationship. Conversely, if the value is less than zero, it is a negative relationship. The correlations were considered significant if the $\mathrm{p}$ value $<0,05$. Nutrisurvey 2007 was used to perform analysis of zinc intake.

\section{Results}

From 70 subjects, the median age was 30 (24-36) months. The majority of subjects had normal nutritional status and family income below UMP DKI Jakarta. Data on subjects' characteristics can be seen in Table 1. 
Table 1. Subjects' characteristics

\begin{tabular}{|c|c|c|}
\hline Characteristics & Mean/Median Value & Results $(\mathrm{n}=70)$ \\
\hline Age (months) & $30(24-36)^{*}$ & \\
\hline \multicolumn{3}{|l|}{ Gender, n (\%) } \\
\hline Male & & $30(42.9)$ \\
\hline Female & & $40(57.1)$ \\
\hline \multicolumn{3}{|l|}{ Nutritional status, $\mathrm{n}(\%)$} \\
\hline Severely wasted & & - \\
\hline Wasted & & $5(7,1)$ \\
\hline Normal & & $63(90)$ \\
\hline Overweight & & $1(1,4)$ \\
\hline Obese & & $1(1,4)$ \\
\hline \multicolumn{3}{|c|}{ Mother' education, n (\%) } \\
\hline Low & & $27(38.6)$ \\
\hline High & & $43(61.4)$ \\
\hline \multicolumn{3}{|l|}{ Family income, n (\%) } \\
\hline$<\mathrm{UMP}$ & & $50(71,4)$ \\
\hline$\geqslant \mathrm{UMP}$ & & $20(28,6)$ \\
\hline \multicolumn{3}{|l|}{ In this } \\
\hline Zinc intake, $\mathrm{n}(\%)$ & $6(1,2-22,5)^{*}$ & \\
\hline Insufficient & & $14(20)$ \\
\hline Sufficient & & $56(80)$ \\
\hline VAS appetite score & $54.8 \pm 20.5^{* *}$ & \\
\hline \multicolumn{3}{|c|}{ Income during pandemic, n (\%) } \\
\hline Decreased & & $53(75,7)$ \\
\hline Same as before & & $15(21,4)$ \\
\hline \multicolumn{3}{|c|}{ Impact of the pandemic on children's } \\
\hline \multicolumn{3}{|l|}{ food, $\mathrm{n}(\%)$} \\
\hline Changed & & $23(32,9)$ \\
\hline Same as before & & $45(64,3)$ \\
\hline \multicolumn{3}{|c|}{ Number of children in the family, $\mathrm{n}(\%)$} \\
\hline One & & $16(22.9)$ \\
\hline Two & & $30(42.9)$ \\
\hline Three or more & & $24(34.3)$ \\
\hline Hair zinc level, n (\%) & $132(30-451)^{*}$ & \\
\hline Insufficient & & $12(17,1)$ \\
\hline Sufficient & & $58(82,9)$ \\
\hline
\end{tabular}

\footnotetext{
* Median (min-max)

** Mean $\pm \mathrm{SD}$
} 
Table 2. Correlation of zinc intake and VAS appetite score with hair zinc level

\begin{tabular}{lcc}
\hline Correlation test & Hair zinc level $\mu \mathrm{g} / \mathrm{g}$ & \\
& $\mathrm{r}$ & $\mathrm{p}$ \\
\hline Zinc intake & -0.077 & 0.528 \\
VAS appetite & 0,247 & $0,039^{*}$ \\
\hline
\end{tabular}

* statistically significant

In this study, the median value of zinc intake was $6(1,2-22,5) \mathrm{mg} /$ day. Compared to Indonesia RDA 2019 adequacy, it was found that $20 \%$ of the subjects had insufficient zinc intake. The results can be seen in Table 1. The median (minimum-maximum) hair zinc value was $132(30-451) \mu \mathrm{g} / \mathrm{g}$. Compared to the cut off value of normal hair zinc level $(\geq 80 \mu \mathrm{g} / \mathrm{g})$, there were $17,1 \%$ subjects with insufficient hair zinc value. The adequacy of hair zinc can be seen in Table 1. The mean \pm SD for VAS appetite assessment by the parents was $54.8 \pm 20.5 \mathrm{~mm}$.

The correlation between zinc intake and VAS appetite with hair zinc levels can be seen in Table 2. There was not significant very weak negative correlation between zinc intake and hair zinc levels $(\mathrm{r}=-0.077, \mathrm{p}=0.528)$. There was a weak positive correlation between VAS appetite and hair zinc levels $(r=0,247, p=0,039)$.

\section{Discussion}

In this study, majority of subjects had adequate zinc intake, $20 \%$ of subjects had insufficient zinc intake. The median intake of zinc was $6(1.2-22.5) \mathrm{mg}$, this result was not much different from the study on children under five in Semarang who got an average zinc intake of $5.2 \pm 2.5 \mathrm{mg}$ with $29.5 \%$ insufficient intake. ${ }^{12}$ Although intake of zinc was adequate, children are still considered as an age group at high risk for zinc deficiency, because the important role of zinc in cell division and protein synthesis is very much needed during the growth period. Indonesia RDA 2019 stated that $3 \mathrm{mg} /$ day is sufficient for children aged 1-3 years with notes that it comes from sources with high and moderate bioavailability. ${ }^{6}$ Zinc with high bioavailability is found in "expensive foods" such as fish and meat. The RDA of zinc for
Southeast Asia should be considered regarding bioavailability of the diet compared to the western diet, Asians generally tend to consume less animal products and more plant products that are rich in phytate. ${ }^{13}$ Approximately $17.3 \%$ of the world's population is at risk of zinc deficiency which can be absorbed, with the highest risk in countries in Southeast and South Asia. ${ }^{14}$ It was found that $82.9 \%$ had adequate hair zinc levels and median hair zinc value was $132(30-451) \mu \mathrm{g} / \mathrm{g}$. The median is similar to the mean hair zinc value in the Brazilian study by Beinner et al. ${ }^{15}$ Beinner got an average hair zinc level $134.3 \pm 110.3 \mu \mathrm{g} / \mathrm{g}$.

This study showed there was not significant very weak negative correlation between zinc intake and hair zinc levels $(r=-0.077, p=0.528)$. This result is similar to the study of Beinner et al. ${ }^{15}$ which found that there was no correlation between zinc intake and hair zinc level in Brazilian children. This result is different from the results of the study by Siahaan which obtained a strong and significant correlation with $(r=0.707, p=0.000)$, but the study was conducted on a population of children with autism. ${ }^{16}$ Another study in children in Brazil concluded that the physiological signs of zinc depletion are described with diverse biochemical functions rather than with specific functions, which makes it difficult to recognize zinc biomarkers. Prolonged and severe decrease in zinc intake can significantly reduce zinc stores in the body. ${ }^{17,18}$ Chronic zinc deficiency can be best assessed by examining hair zinc levels. ${ }^{15} \mathrm{It}$ was also found in this study that adequate zinc intake had higher mean of hair zinc levels $(169.93 \pm 112.009)$ compared to the group with inadequate zinc intake $(137.07 \pm 79.11)$, but this increase was not significant (Table 3). This result is also similar with Beinner's study where in the increased zinc consumption group, the average hair zinc level also increased, but this increase was also not significant. There was a weak positive correlation between VAS appetite and hair zinc levels $(r=0,247, p=0,039)$. This indicates with adequate zinc status, children appetite tend to be good, and the otherwise. This is similar to the study of Daniels et al. ${ }^{19}$ which obtain that increased food fussiness score or lack of appetite may result in decrease zinc concentration, or increase in zinc 
Table 3. Average hair zinc levels based on categorized variable

\begin{tabular}{llll}
\hline Variable & $\mathrm{n}=70$ & $\begin{array}{l}\text { Hair zinc level } \mu \mathrm{g} / \mathrm{g} \\
(\text { mean } \pm \text { SD) }\end{array}$ & $\mathrm{p}$ \\
\hline Zinc intake & 14 & $137,07 \pm 79,11$ & $0,45^{\mathrm{mw}}$ \\
$\quad$ Insufficient & 56 & $169,93 \pm 112,009$ & \\
Sufficient & & & \\
VAS appetite & 11 & $124.36 \pm 66.22$ & $0,049^{\mathrm{kw}}$ \\
Poor $(<40)$ & 39 & $147.38 \pm 101.025$ & \\
Acceptable $(40-70)$ & 20 & $215.95 \pm 119.167$ & \\
Good $(>70)$ & & & \\
& & & \\
\hline
\end{tabular}

$\mathrm{mw}=$ Mann Whitney, $\mathrm{kw}=$ Kruskal

concentration could result in a lower food fussiness score or bigger appetite.

Zinc is required for the metabolic activity of 300 enzymes of the body, and is essential for cell division and the synthesis of DNA and proteins. This enzyme is involved with the metabolism of proteins, carbohydrates, and fats. Zinc is also important for wound healing, taste acuity, tissue growth and maintenance, immune system function, prostaglandin production, bone mineralization, thyroid function, blood clotting, cognitive function. ${ }^{7}$ Hence when zinc needs are not met, it will affect optimal child growth and development. Therefore, this study took subjects aged 2 to 3 years old because this period is an important transition period from children eating complimentary food to family food, and optimal time to catch up growth after the golden period, where if there is insufficient nutrients such as zinc, it can be quickly resolved. Based on Indonesian RDA, the recommendation of zinc consumption in children aged $2-3$ years is 3 $\mathrm{mg} /$ day. ${ }^{6}$ Hopefully zinc needs can be fulfilled from variety of foods that are rich in zinc. Food rich in zinc include seafood, meat, whole grains, nuts, and dairy products. Most developing countries had children lack the intake of foods rich in easily absorbed zinc, such as liver, red meat, poultry, and seafood. The difference between zinc intake and absorption must be considered, because even if zinc intake is adequate, levels of inhibitors (fiber and phytate) in the diet can prevent zinc from being absorbed adequately. Traditional staple foods, such as cereals, and legumes contain zinc, but the presence of phytates, fiber, and lignin reduces their bioavailability. These substances form insoluble complexes with zinc and prevent its absorption. ${ }^{7}$ Although the median of zinc intake of subjects in this study (6 mg/day) was higher than the recommendation in Indonesian RDA, however $20 \%$ of the subjects did not have sufficient zinc intake. Continuous lack of zinc intake will cause decrease in the body's zinc reserves. A study by Jackson et al. ${ }^{20}$ on experimental animals, found zinc loss was not similar in all tissues. Hair, skin, heart and muscle zinc levels remained constant, while plasma, liver, bone zinc levels fell significantly. It is interesting that hair zinc concentrations did not change in this experimental animal study. Hair zinc levels are expected to change with marginal intake over the long term but not with severe depletion as studied in these experimental animals. ${ }^{20}$

Questionnaire of VAS was filled in by the subject's parents by marking with a vertical sign on a $100 \mathrm{~mm}$ horizontal line based on how they currently feel about the child's appetite with consideration that the extreme labels at both ends were the least hungry and the most hungry the child had experienced so far. In this study, mean of VAS score was $54,5 \mathrm{~mm}$. When compared to the cut off from El Sayed Ahmad et al. ${ }^{21}$ study in pediatric patients of tonsillotomy which categorized between 40 and $70 \mathrm{~mm}$ as "acceptable appetite", the mean 
VAS score of this study can be said to be "acceptable appetite". The plausible mechanism for correlation between appetite score and hair zinc status as showed in Daniels et al. ${ }^{19}$ study if toddler is lack of appetite or food fussy, then they may eat fewer foods that are high in zinc, and zinc status could decreased. However, there is also evidence for the opposite pathway from low zinc status to decrease appetite. Lower zinc status can result in impaired taste acuity in children $22,23,24$, which may result in lower appetite. $^{25}$

Zinc plays a role in activating areas of the brain that receive and process information from taste and smell sensors. So that zinc levels affect taste, taste preferences and increase taste sharpness. ${ }^{26}$ Research shows that zinc can increase appetite, energy intake and increase fat-free mass. ${ }^{27}$ Zinc can increase calorie intake because it can increase children's appetite. ${ }^{28}$ Research conducted animal studies have shown that oral zinc administration rapidly stimulates food intake during early-stage zinc deficiency without decreasing plasma and tissue zinc concentrations. Zinc supplementation increases appetite and weight in children with poor appetite and growth failure due to unspecified causes. In a study of zinc supplementation in malnourished children conducted in Taiwan, it was found that the effect of increasing appetite was significantly better in children whose initial zinc level was low. ${ }^{3}$ Other studies have shown that zinc supplementation can increase appetite and caloric intake in children aged 2-6 years. ${ }^{28}$ Zinc also stimulates the growth and function of taste buds on the tongue, thereby affecting appetite. ${ }^{29,30} \mathrm{Zinc}$ is a component of gustin, an important protein involved in sharpness of taste. ${ }^{8}$

There were some limitation of this study. It was carried out during the Covid-19 pandemic, thus limited available resources in the data collecting. The parents of prospective subject were also hesitate to participate because concerning of pandemic situation. There are also possibility of memory bias during assessment zinc intake of children with SQFFQ.

\section{Conclusion}

From this study it can be concluded that zinc intake had no significant correlation with hair zinc level. Another finding in this study, appetite had a positive correlation with hair zinc level. Among subjects there are $20 \%$ that had zinc intake below the daily requirement. Zinc is needed in the development and growth of children, thus it is important to pay attention the adequacy of zinc intake. Health service centers can provide counseling to parents during visits regarding the importance of zinc sources for children's health and growth, instructions for the amount of zinc sources, especially from animal sources that are affordable for the community. Information needs to be carried out either directly or through social media, for example through infographics, regarding the importance of adequate intake of nutrients to meet the needs of zinc which can support children's growth and health. Further research is needed on zinc intake and status by considering albumin status, and grouping zinc sources from high and low bioavailability.

\section{Conflict of Interest}

Authors declared no conflict of interest regarding this article.

\section{Acknowledgment}

We would like to convey our gratitude to all those who helped in this study, including but not limited to, the study subjects, Puskesmas Kampung Melayu and its sub-district office. The authors would like to thank Universitas Indonesia for funding this research though PUTI Grant with contract number NKB-4707/UN2.RST/HKP.05.00/2020

\section{Open Access}

This article is distributed under the terms of the Creative Commons Attribution 4.0 International Licence

(http://creativecommons.org/licenses/by/4.0/), which permits unrestricted use, distribution, and reproduction in any medium, provided you give appropriate credit to the original author(s) and the 
source, provide a link to the Creative Commons license, and indicate if changes were made.

\section{References}

1. Nasar SS, Pulungan BA. Masalah makan pada anak. Makalah lengkap konggres nutririon growthdevelopment, continuing professional development IDAI, Jakarta; 2006, hal. 53-68

2. Dewi A. Gambaran asupan zat gizi mikro pada balita di Kota Semarang. Journal of Nutrition and Health. 2015; 3(2)

3. Chao HC, Chang YJ, Huang WL. Cut-off Serum Zinc Concentration Affecting the Appetite, Growth, and Nutrition Status of Undernourished Children Supplemented With Zinc. Nutrition in Clinical Practice published, American Society for Parenteral and Enteral Nutrition. Wiley Periodicals Inc. 2018;33(5):701-9

4. Caulfield LE, Black RE. Zinc deficiency. Diakses tanggal 6 Maret 2020 :www.who.int/publications/cra/ chapters/volume1/0257-0280pdf.

5. Gibson RS. Principle of Nutritional Assessment.Second edition.Oxford University Press. 2005: p.380.

6. Kemenkes. Peraturan Menteri Kesehatan Republik Indonesia nomor 28 tahun 2019 tentang angka kecukupan gizi yang dianjurkan untuk masyarakat Indonesia, 2019.

7. Deshpande JD, Joshi MM, Giri PA. Zinc: The Trace Element Of Major Importance In Human Nutrition And Health. International Journal of Medical Science and Public Health. Vol 2 Issue 1. 2013;1-4.

8. Stubbs RJ, Hughes DA, A, Johnstone M, Rowley E, Reid C, Elia M, Stratton R, Delargy H, King N, Blundell JE. The use of visual analogue scales to assess motivation to eat in human subjects: a review of their reliability and validity with an evaluation of new handheld computerized systems for temporal tracking of appetite ratings. British Journal of Nutrition. 2000, 84, p405

9. Allison DB, Baskin ML. Handbook of assessment methods for eating behaviours and weight-related problems. Second edition. SAGE publication. 2009, p454-6, 296-9

10. Alarcon PA, Lin LH, Noche M, Hernandez VC, Cimafranca L, Lam W, Comer GM. Effect of oral supplemental on catch-up growth in picky eaters. Clin Pediatr 2003;42:209-17.

11. Huynh DT, Estorninos E, Capeding RZ, Oliver JS, Low YL, Rosales FJ. Longitudinal growth and health outcomes in nutritionally at-risk children who received long-term nutritional intervention. J Hum Nutr Diet 2015;28:623-35.

12. Sundari E, Nuryanto. Hubungan Asupan Protein, Seng, Zat Besi, dan Riwayat Penyakit Infeksi dengan Z-Score
TB/U pada Balita, Journal of Nutrition College Volume 5, Nomor 4, $2016: 520-529$

13. Tee ES, Florentino R. Recommended Dietary Allowances (RDA) Harmonization in Southeast Asia. Monograph Series. Singapore: International Life Sciences Institute, Southeast Asia Region, 2005

14. Galetti V. Zinc Deficiency and Stunting. Pada: Preedy V., Patel V. (eds) Handbook of Famine, Starvation, and Nutrient Deprivation. Springer, Cham. 2018. https://doi.org/10.1007/978-3-319-40007-5_93-1

15. Beinner MA, Menezes MADBC, da Silva JBB, de Amorim FR, Jansen AK, Lamounier JA. Plasma Zinc and Hair Zinc Levels, Anthropometric Status and Food Intake of Children in a Rural Area of Brazil, Revista de Nutricao, 2010

16. Siahaan DK. Hubungan Asupan Seng (Zn) dan Protein terhadap Kadar Seng (Zn) Rambut pada Anak Autis di Kota Medan, 2019. http://repo.poltekkesmedan.ac.id/xmlui/handle/123456789/1045

17. Cousins RJ. Systemic transport of zinc. In: Mills CF, editor. Zinc in human biology. New York: SpringerVerlag; 1989. pp. 79-93. [Google Scholar] [Ref list]

18. Han TH, Lee J, Kim YJ. Hair Zinc Level Analysis and Correlative Micronutrients in Children Presenting with Malnutrition and Poor Growth. Pediatr Gastroenterol Hepatol Nutr. 2016;19(4):259-268. doi:10.5223/pghn.2016.19.4.259

19. Daniels L, Williams SM, Gibson RS, Taylor RW, Samman S, Heath AM. Modifiable "Predictors" of Zinc Status in Toddlers. Nutrients. 2018 Mar 5;10(3):306. doi: 10.3390/nu10030306. PMID: 29510562; PMCID: PMC5872724.

20. Jackson, M. J., Jones, D. A. Edwards, R.H.T. Tissue zinc levels as an index of body zinc status. Clin. Physiol.1982, 2:333-343.

21. El Sayed Ahmad Y, Nehme J, Moukarzel N. Comparison of Postoperative Pain and Appetite in Pediatric Patients Undergoing Monopolar Tonsillotomy and Cold Steel Tonsillectomy. Int J Otolaryngol. 2020;2020:8060971. Published 2020 May 18. doi:10.1155/2020/8060971

22. Cavan, K.R.; Gibson, R.S.; Grazioso, C.F.; Isalgue, A.M.; Ruz, M.; Solomons, N.W. Growth and Body Composition of Periurban Guatemalan Children in Relation to Zinc Status-A Cross-Sectional Study. Am. J.Clin. Nutr. 1993, 57, 334-343.

23. Buzina, R.; Jusi'c, M.; Sapunar, J.; Milanovi'c, N. Zinc nutrition and taste acuity in school children with impaired growth. Am. J. Clin. Nutr. 1980, 33, 22622267.

24. Gibson, R.S.; Vanderkooy, P.; MacDonald, A.C.; Goldman, A.; Ryan, B.A.; Berry, M. A GrowthLimiting, Mild Zinc-Deficiency Syndrome in Some Southern Ontario Boys with Low Height Percentiles. Am. J. Clin. Nutr.1989, 49, 1266-1273.

25. Hambidge, K.M.; Hambidge, C.; Jacobs, M.; Baum, J.D. Low-Levels of Zinc in Hair, Anorexia, Poor Growth, and Hypogeusia in Children. Pediatr. Res. $1972,6,868-874$. 
26. Kusumastuti AC, Ardiaria M, Hendrianingtyas M, Effect of Zinc and Iron Supplementation on Appetite, Nutritional Status and Intelligence Quotient in Young Children, The Indonesian Biomedical Journal, Vol.10, No.2, August 2018, p.133-9

27. Arsenault JE, Romaña DL, Penny ME, Loan MDV, Brown KH. Additional zinc delivered in a liquid supplement, but not in a fortified porridge, increased fat-free mass accrual among young peruvian children with mild-to-moderate stunting. J Nutr. 2008; 138: 10814

28. Khademian M, Farhangpajouh N, Shahsanaee A, Bahreynian M, Mirshamsi M Kelishadi R. Effects of zinc supplementation on subscales of anorexia in children: A randomized controlled trial. Pak J Med Sci. 2014; 30: 1213-7.

29. Suzuki H, Asakawa A, Li JB, Tsai M, Amitani H, Ohinata K, et al. Zinc as an appetite stimulator - the possible role of zinc in the progression of diseases such as cachexia and sarcopenia. Recent Patents on Food, Nutrition \& Agriculture (2011) 3: 226-31. Bentham Science Publisher

30. Yagi T, Asakawa A, Ueda H, Ikeda S, Inui SMA. The role of zinc in the treatment of taste disorders. Recent Pat Food Nutr Agric. 2013; 5: 44-51. 